\title{
Determining reference conditions of hemiboreal lakes in Latvia, NE Europe: a palaeolimnological approach
}

\author{
Normunds Stivrins ${ }^{1,2,3,4, *}$, Ieva Grudzinska ${ }^{3,5,6,7}$, Kati Elmi ${ }^{4}$, Atko Heinsalu ${ }^{4}$ and Siim Veski ${ }^{4}$ \\ ${ }^{1}$ Department of Geography, Faculty of Geography and Earth Sciences, University of Latvia, Riga, Jelgavas street 1, 1004, Latvia \\ 2 Department of Geosciences and Geography, University of Helsinki, P.O. Box 64, Helsinki 00014, Finland \\ ${ }^{3}$ Lake and Peatland Research Centre, Alojas district, Puikule, Purvisi, Latvia \\ ${ }^{4}$ Institute of Geology, Tallinn University of Technology, Ehitajate tee 5, 19086 Tallinn, Estonia \\ ${ }^{5}$ Institute of Plant Sciences, University of Bern, Altenbergrain 21, CH-3013 Bern, Switzerland \\ ${ }^{6}$ Oeschger Centre for Climate Change Research, University of Bern, Falkenplatz 16, CH-3013 Bern, Switzerland \\ ${ }^{7}$ Institute of Biology, University of Latvia, Miera iela 3, Salaspils 2169, Latvia
}

Received: 28 November 2017; Accepted: 7 May 2018

\begin{abstract}
The current status of a lake can be evaluated via monitoring, but such data can only provide information about the last few decades to a century at best. In most cases, the natural state of a lake cannot be ascertained. This is even more challenging if the apparent anthropogenic effects on the environment over the last millennia are considered. We used data on fossil algae from five evenly distributed hemiboreal lakes in geographically different regions in Latvia, NE Europe to assess the amount of compositional change or turnover (i.e., the beta-diversity) in the algae datasets for the last 2000 years by using a Detrended Canonical Correspondence Analysis. Our results show that the algae turnover increases towards the present day with distinct shifts during times characterised by extensive and intensive agriculture establishment, and political and economic changes. Because the anthropogenic impact on the landscape and lakes before AD 1200 was relatively minor, we propose that algae composition at that time can be assumed to represent the natural reference conditions for most Latvian lakes.
\end{abstract}

Keywords: Algae / anthropogenic impact / turnover rates

\section{Introduction}

Water covers most of the world's surface, but only a tiny portion is freshwater that provides critical ecosystem services to humans (Smol, 2008; O'Reilly et al., 2015). Freshwater ecosystems are considered to be among the most threatened on the planet (IPCC, 2014). The impact of climate and anthropogenic activity are two of the most important factors that affect freshwater lakes in the Northern Hemisphere (Douglas and Smol, 1999; Smol et al., 2005). Extensive climate warming over the last few decades has affected the lake water temperatures (Smith et al., 2015). Increasing thermal stratification of the water bodies can lead to blooms of harmful and toxic cyanobacteria (Paerl and Huisman, 2008; De Senerpont Domis et al., 2013; O'Reilly et al., 2015). Human activities that vary temporally and spatially leave even more pronounced footprints in lakes (Bradshaw et al., 2005;

\footnotetext{
*Corresponding author: normunds.stivrins@lu.lv
}

Battarbee and Bennion, 2011; Weckström et al., 2015; Marzecová et al., 2017). Through eutrophication caused by agricultural activity, soil leaching, over nutrient in-washing of sewage, and manure and fertilizer, biotic processes are changing in the lakes and also affect terrestrial ecosystems (Bellinger and Sigee, 2010; Alliksaar and Heinsalu, 2012; Soininen et al., 2015; Steffen et al., 2015; Mikomägi et al., 2016). It is very likely that, due to the increasing stress from urbanisation and agricultural activity, freshwater ecosystems will continue to face changes in biodiversity and productivity (Schiefer et al., 2013; Douglas and James, 2015; Liu et al., 2016).

Establishing the susceptibility and trophic changes in lake ecosystems is an important management issue on a local and regional scale. To assess the degree of damage to a lake ecosystem, it is necessary to compare present-day conditions with natural or reference conditions. Reference conditions represent a lake ecosystem in the absence of significant anthropogenic impact (Smol, 2008). Commonly used lake monitoring data can provide information about lake status for 
the last few decades to a century at best, but in most circumstances, no one can truly reveal the natural state of a lake. This is even more challenging if the apparent anthropogenic effects on the environment over the last millennia are considered. Over the last decade, lake reference conditions were established for many countries, mainly according to the Water Framework Directive of the European Union (EC, 2000; Heinsalu and Alliksaar, 2009a, b; Hering et al., 2010). In this context, a palaeolimnological approach that employs the algae microfossil record (algal remains that preserve in the lake sediments after their death) has been considered as one of the most influential approaches for determining the past lake ecological status (EC, 2000). This approach provides long-term data (centurial to millennial) that is not achievable using standard monitoring programmes. Furthermore, valuable insight can be gained from sparsely sampled time series and well-positioned isolated samples before and after significant biotic or environmental events or transitions. To the best of our knowledge, a palaeolimnological approach, mainly via the algae microfossil record, has not been applied to evaluate the status and reference conditions of freshwater hemiboreal lakes in Latvia, northeastern Europe. Hence, the scientifically validated throughput method used in this study can provide an assessment of water quality and establish general reference conditions for hemiboreal lakes.

This study aims to determine a possible timing of reference conditions for hemiboreal lakes in Latvia, NE Europe using a palaeolimnological approach. We used the algae microfossil record from five freshwater lakes that are evenly distributed in geographically different regions in Latvia to evaluate the algae compositional turnover (beta-diversity) over the last 2000 years - a time from minor to intensive anthropogenic pressure on lake ecosystems. Selected statistical method for the current study, such as a Detrended Canonical Correspondence Analysis (DCCA) has been successfully used to evaluate the phytoplankton communities of lakes (e.g., Smol et al., 2005; Weckström et al., 2015), which can be used in assession of regime shifts and finding the reference conditions.

\section{Study area}

\subsection{History of human impact on the landscape over the last 2000 years}

Palaeovegetation records from the study sites indicate a heavily wooded landscape until $500 \mathrm{BC}$ when the first traces of the continuous record of cereal pollen indicate the establishment of agriculture. However, agriculture during the Iron Age was relatively minor and did not dramatically change the surrounding landscape with few exceptions regarding specific dwellings and cultural aspects (Stivrins et al., 2015a). Agricultural practices varied within and between the Baltic region; at least a 4000-year cultivation history is observed close to settlement centres, but agriculture began much later in peripheral areas.

The first most significant changes in the vegetation and environment during the last 2000 years occurred during the Medieval and post-Medieval period roughly at AD 12001850. The Medieval period in the Baltic was dominated by the Crusades, a holy war led by the military orders and bishops that conquered modern-day Latvia, Estonia and western Lithuania

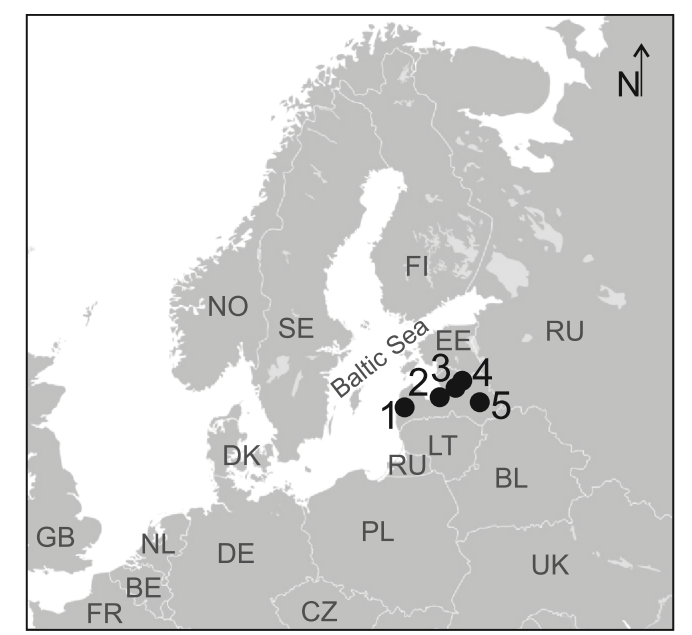

Fig. 1. Location of the study area (Latvia) and the five lakes in the present study: (1) Ķikuru; (2) Lilaste; (3) Āraišu; (4) Trikātas; (5) Lielais Svetinu.

during the 13th century, with the aim of converting the indigenous pagan tribal societies to Christianity (Brown and Pluskowski, 2014). The conquest of tribal land during the Crusades resulted in changes in the ownership, administration and organisation of the land, and palaeorecords indicate that the landscape changed immediately following the Crusades (Stivrins et al., 2016a), or the century after the Crusades, since the 14th century and later. Overall, this period is characterised by an increase in agriculture and land-use in Latvia that required a vast amount of human labour.

The reduction of the land-use area and a shift from an extensive to an intensive farming economy, which requires less human labour, occurred with the onset of the Industrial Revolution at this region roughly at AD 1850. Industrialization and the accompanying increase in the population density caused increased environmental pressure in many areas due to higher inputs of effluent from industrial and human activity, particularly following construction adjacent to a lake (Stivrins et al., 2016a). Hence, the eastern Baltic has undergone significant social, cultural and economic changes over the last 2000 years from a relatively mute to distinct anthropogenic impact on both the landscape and aquatic ecosystems (Veski et al., 2005; Brown and Pluskowski, 2014; Stivrins et al., 2016a).

\subsection{Present environmental conditions, setting and site selection}

The study area in Latvia is situated $55-58^{\circ} \mathrm{N}$ and $20-28^{\circ} \mathrm{E}$ in northeastern Europe (Fig. 1) in the hemiboreal forest zone, which is characterized by a mixture of hemiboreal coniferous and deciduous tree species such as the Norway spruce (Picea abies), Scots pine (Pinus sylvestris), birches (Betula spp.), alders (Alnus glutinosa, Alnus incana), mountain elm (Ulmus glabra), ash (Fraxinus excelsior), lime (Tilia cordata) and oak (Quercus robur). A combination of a continental (Eurasia) and maritime (Atlantic Ocean) climate is typical for this area and is more continental in the east and more maritime in western Latvia. The average annual air temperature in Latvia is $+6^{\circ} \mathrm{C}$, 
Table 1. Information of the studied lakes.

\begin{tabular}{|c|c|c|c|c|c|}
\hline Lake & Area, ha & $\begin{array}{c}\text { Mean/max } \\
\text { water depth, m }\end{array}$ & $\begin{array}{l}\text { Elevation } \\
\text { m a.s.1. }\end{array}$ & Coordinates & Related reference \\
\hline Ķikuru & 21.6 & $2 / 4.3$ & 38.7 & $56^{\circ} 48^{\prime} \mathrm{N} ; 21^{\circ} 37^{\prime} \mathrm{E}$ & Stivrins et al., (2017), but for algae current issue \\
\hline Āraišu & 32.6 & $4 / 12.3$ & 120.2 & $57^{\circ} 15^{\prime} \mathrm{N} ; 25^{\circ} 17^{\prime} \mathrm{E}$ & Stivrins et al., (2015a) \\
\hline Trikātas & 13 & $4 / 4.2$ & 50 & $57^{\circ} 32^{\prime} \mathrm{N} ; 25^{\circ} 42^{\prime} \mathrm{E}$ & Stivrins et al., (2016a), but for algae current issue \\
\hline Lielais Svetiņu & 18.8 & $4 / 4.3$ & 96.2 & $56^{\circ} 45^{\prime} \mathrm{N} ; 27^{\circ} 08^{\prime} \mathrm{E}$ & Stivrins et al., (2015b) \\
\hline
\end{tabular}

$+17^{\circ} \mathrm{C}$ in July and $-4.7^{\circ} \mathrm{C}$ in January, and the annual precipitation in average reaches $670 \mathrm{~mm}$ according to the Ltd. Latvian Environment, Geology and Meteorology Centre data. The present-day topography has primarily been formed as a result of the Weichselian glaciation and the subsequent deglaciation (Zelčs et al., 2011). Overall, Latvia is rather flat with an average altitude of approximately $100 \mathrm{~m}$ a.s.l. and the maximum elevation is $312 \mathrm{~m}$ a.s. 1 .

The fossil algae records of the last 2000 years from small to large lakes were selected for the current study (Tab. 1). The selected lakes represent different environmental and geographical localities such as near shore, lowland and upland, which is vital as we determine the overall change in the algal composition of Latvian lakes.

Although our study is based on "one-core data", it has been assumed as sufficiently representative of trophic state changes of either small or large body of water (Smol, 2008). Smaller lakes' sediment core records tend to reflect local compositional changes over time, while larger bodies of water might display a uniform picture in general (larger bodies of water experience a broader range of environmental conditions). Responses of communities at large-scale levels are slow and often imprecise, but their ecological relevance is high due to the accumulating effects of disturbances or stresses on the system (Park, 2016). In this context, the advantage of a palaeolimnological approach is that for either a small or a large lake, it indicates conditions that existed before significant anthropogenic effects, which is the primary data necessary to determine the reference conditions or the so-called baseline to compare to the present-day situation.

We used two types of fossil algae remains. In the current study, we use term "diatoms" exclusively for diatoms, but "microscopic Chlorophyta and Cyanophyta" indicates algae other than diatoms. Diatoms are a group of microscopic algae abundant in almost all aquatic habitats that are one of the most common types of phytoplankton. They are unicellular organisms with a silica cell wall. Microscopic Chlorophyta and Cyanophyta have been identified during pollen analysis, and the most common taxa of these groups comprise Anabaena, Aphanizomenon, Botryococcus, Coelastrum, Gloeotrichia, Glaucospira, Rivularia, Pediastrum, Staurastrum, Scenedesmus and Tetraëdron (Stivrins et al., 2015b). Even though sample preparation methods are different, diatoms and microscopic Chlorophyta and Cyanophyta represent algae living in the lake at the particular time. It is important to note that the algae identified from sediment samples do not reflect the complete taxonomic diversity due to complex taphonomic preservation processes (Stivrins et al., 2018).
Selected sites in the current study are lakes located in geographically different locations. Lake Kikuru (21.6 ha, $38.7 \mathrm{~m}$ a.s.1., max water depth $4.3 \mathrm{~m}$ ) is located in western Latvia $\left(56^{\circ} 48^{\prime}\right.$ N. $21^{\circ} 37^{\prime}$ E; Fig. 1). Geologically, the ground consists of Quaternary (Pleistocene) sediments - till and limnoglacial-glaciolacustrine sediments of 4.4-18 m thick. The lake has a flow-through hydrological regime. It is surrounded by open fields and sparse stands of pine and birch (Stivrins et al., 2017). A former dairy is located next to the lake and ejected wastewater into the lake approximately in 1970-1990. The lake is the dystrophiceutrophic type.

Lake Lilaste (183.6 ha, $0.5 \mathrm{~m}$ a.s.1., max water depth $3.2 \mathrm{~m})$ is a drainage lake located on the Coastal Lowland $\left(57^{\circ} 10^{\prime} \mathrm{N}, 24^{\circ} 21^{\prime} \mathrm{E}\right)$, approximately $20 \mathrm{~km}$ north-east of Riga (the capital of Latvia), and one km east of the Gulf of Riga. Quaternary deposits of $45 \mathrm{~m}$ consist of till, glaciolacustrine and marine silt, sand and aeolian sediments. Pine forest and bogs cover the catchment area. Today, treated wastewater from the residential area is discharged into the lake creating anthropogenic stress (Grudzinska et al., 2017). The lake is the mesotrophic-dystrophic type.

Lake Āraišu (32.6 ha, $120.2 \mathrm{~m}$ a.s.1., max water depth $12.3 \mathrm{~m})$ is located in central Latvia $\left(57^{\circ} 15^{\prime} \mathrm{N}, 25^{\circ} 17^{\prime} \mathrm{E}\right)$, on the western edge of the Vidzeme Upland. The geology is Devonian sandstone overlain by $80 \mathrm{~m}$ of till. It has a flow-through hydrological regime. The size of the catchment area is $10 \mathrm{~km}^{2}$. An open-air Iron Age lake-dwelling is located in the lake, and a few active and former farms surround the lake. The lake is the eutrophic-hypereutrophic type.

Lake Trikātas (13 ha, $50 \mathrm{~m}$ a.s.1., max water depth $6.5 \mathrm{~m}$ ) is situated in northern Latvia $\left(57^{\circ} 32^{\prime} \mathrm{N}, 25^{\circ} 42^{\prime} \mathrm{E}\right)$, in the northern Vidzeme lowland. The lake is located in a $25-\mathrm{m}$ deep valley with an outflow connected to the River Abuls. Quaternary glacial till and alluvial deposits in the Trikātas area overlie Devonian sandstone bedrock. The surrounding landscape comprises a mixture of cultivated land and pasture overlaying sandy and podzolic soils. A former distillery, a dairy, and a working primary school are located next to the lake. The lake is the eutrophic-hypereutrophic type.

Lake Lielais Svetinu (18.8 ha, $96.2 \mathrm{~m}$ a.s.1., max water depth $4.9 \mathrm{~m})$ is located in eastern Latvia $\left(56^{\circ} 46^{\prime} \mathrm{N}, 27^{\circ} 08^{\prime} \mathrm{E}\right)$, in the Eastern Latvian Lowland. The bedrock consists of Devonian dolomite covered by Quaternary deposits with a thickness of 5-10 m consisting of sand, silt and clay. Lake Lielais Svetinu is a drainage lake with a catchment of $12 \mathrm{~km}^{2}$, which is predominantly forested but also partly covered by fields. The lake is the mesotrophic-dystrophic type. 


\section{Materials and methods}

\subsection{Fieldworks}

Fieldworks to obtain the gyttja sediment from the lakes were conducted from the ice-covered surface in Lake Lielais Svetinu on March 2009, in Lake Trikātas on March 2012, in Lake Āraišu on March 2012, in Lake Kikuru on March 2013, and in Lake Lilastes on April/March 2012 and 2013 (Stivrins et al., 2015a, 2015b, 2017; Grudzinska et al., 2017). The uppermost unconsolidated sediment was sampled using a Willner-type sampler and subsequent denser sediment using a $10-\mathrm{cm}$ diameter Russian peat sampler that possesses a $1-\mathrm{m}$ long barrel. In a current study, only sediment covering last 2000 years were included and analysed as it sufficiently covers period revealing prior-, during and post-human situation.

\subsection{Chronology}

Previously, published original radiocarbon dates from all sites were recalibrated with the IntCal13 calibration dataset (Reimer et al., 2013) with a two $\sigma(95.4 \%)$ confidence level and the age-depth models of each sequence were developed using the Bacon 2.2.software package (Blaauw and Christen, 2011) in the R environment (version 3.0.3) (R Core Team, 2014). A load of spheroidal carbonaceous particles (SCP) along the upper sediment sequence was estimated for Lake Kikuru and followed the methodology of Rose (1990) and Alliksaar (2000). The peak in SCP emission occurred in AD $1982 \pm 10$ years (Stivrins et al., 2016b). Information on SCP was already available from Lake Āraišu (Stivrins et al., 2015a) and Lilaste (Grudzinska et al., 2017). Also, microscopic volcanic ash shards - tephra of Askja AD 1875 eruption was used for lakes Āraišu and Trikātas (Stivrins et al., 2016b) in the age-depth modelling.

\subsection{Analysed algae}

Most of the algal data have been previously published except for Ķikuru and Trikātas, which are presented here for the first time (Tab. 1, Fig. 1). Diatoms from Lake Trikātas were analysed at 16 stratigraphical levels, i.e., 16 samples. The diatom samples were pre-treated according to Battarbee et al. (2001). Each subsample had a volume $0.2 \mathrm{~cm}^{3}$ in Lake Trikāta and $0.5 \mathrm{~cm}^{3}$ in Lake Âraišu and Lake Lilaste. At least $400-500$ diatom valves were counted and identified for each depth. The diatom taxonomy was based primarily on Krammer and Lange-Bertalot (1986, 1988, 1991a, b) and Witkowski et al. (2000). Numbers of diatoms were expressed as percentages. Seven microscopic Chlorophyta and Cyanophyta samples from Lake Ķikuru were identified during a pollen analysis, so seven samples were prepared by routine pollen preparation methods that include digestion of a $1 \mathrm{~cm}^{3}$ subsample with $10 \%$ $\mathrm{HCl}, 10 \% \mathrm{KOH}$ and acetolysis for $3 \mathrm{~min}$ (Berglund and Ralska-Jasiewiczowa, 1986). Afterwards, percentages of microscopic Chlorophyta and Cyanophyta were estimated based on the total sum of algae of each sample (Stivrins et al., 2018) and separately for diatoms according to commonly used approach as described in Battarbee et al. (2001). Altogether 23 and 12 samples for diatoms were analysed in Lake Āraišu and
Lake Lilaste, respectively. Microscopic Chlorophyta and Cyanophyta were analysed in Lake Āraišu (36 samples) and Lake Lielais Svetinu (nine samples).

\subsection{Loss-on-ignition}

The water quality in freshwater systems is primarily dependent on material loading through hydrological processes within watersheds (Wang et al., 2015). Agricultural and forest clearance activities around the lakes lead to soil erosion amplification that can be recognised as increased mineral matter content in sediment. Hence, to underline timing of increased soil erosion delivering additional nutrients to the lake, mineral matter content was estimated following Heiri et al. (2001). A known volume of sediment was combusted at $550{ }^{\circ} \mathrm{C}$ for four $\mathrm{h}$ to determine the organic matter content and the ignition residue was estimated as the mineral matter content of the sediment. Altogether 157 samples for Lake Ķikuru, 231 samples for Lake Âraišu, 80 samples for Lake Lilaste, 118 samples for Lake Trikātas and 127 samples for Lake Lielais Svetinu were analysed. Alongside pollen data from studied sites, mineral matter content serves as an independent proxy of environmental changes.

\subsection{Statistical analyses}

The amount of compositional change or turnover (i.e., the beta-diversity) in the algae datasets for the last 2000 years was estimated by using a DCCA. This is the constrained form of the Detrended Correspondence Analysis that uses age as the external constraint, i.e., environmental data ( $\mathrm{Smol}$ et al., 2005; Birks, 2007). A DCCA expresses the compositional turnover in standard deviation units (SD), and the turnover is estimated as the difference between the highest and lowest values for each time sequence (Birks, 2007; Birks and Birks, 2008). A complete turnover of species with no species in joint at either end of the gradient would have a gradient length of 4 SD (Hill and Gauch, 1980) or 100\% of the total changes in sequence. The percentage data for each site was square-root transformed and detrended by segments with no downweighting of rare taxa and non-linear rescaling. Importantly, an individual DCCA was performed for each site in the same way for the last 2000 years using CANOCO 5.04 (ter Braak and Šmilauer, 2012).

\section{Results}

\subsection{Chronology}

The sediment chronology for all sites indicates a somewhat constant sediment accumulation rate (Fig. 2) with higher sedimentation towards the present day, which is also indicated by the less compacted sediment at the top of the sediment profile. Larger uncertainty bands were observed for Lake Lielais Svetinu and somewhat for Lake Lilaste. However, the Lake Lilaste age-depth certainty increases with the SCP. The remainder of the sediment sequences has acceptable age-depth models, which have narrower uncertainty bands due to the application of various dating techniques, such as ${ }^{14} \mathrm{C}$, SCP and tephrochronology. Age-depth models were constructed for 

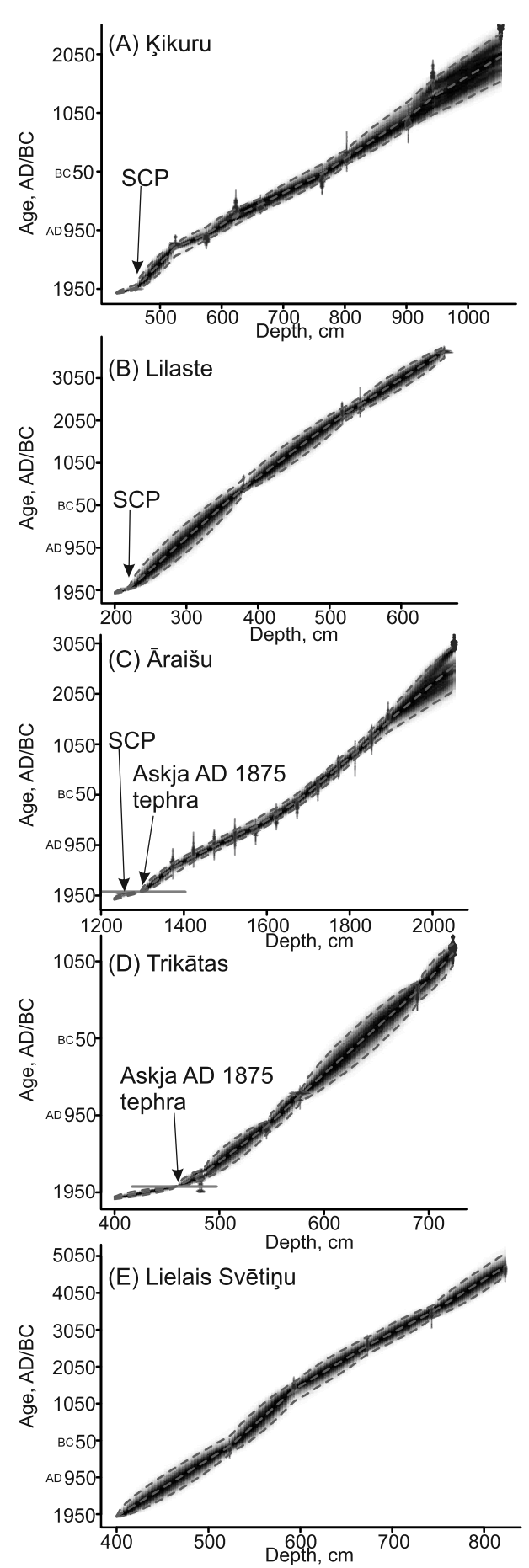

Fig. 2. Age-depth model of (A) Lake Ķikuru, (B) Lake Lilaste, (C) Lake Āraišu, (D) Lake Trikātas and (E) Lake Lielais Svetinu. The SCP (spheroidal carbonaceous particles) and the tephra of Askja AD 1875 eruption are indicated. Rest of the dates are ${ }^{14} \mathrm{C}$. The dotted middle curve shows the weighted mean ages of all depths, whereas the greyscale shows uncertainties (a darker shade of grey indicates a more certain section).

longer time spans than the last 2000 years to show that the sediment accumulation rate for these sites was constant and did not abruptly change. However, note that minor changes in the sedimentation rates began at approximately AD 1200 in Lake
Kikuru, which might be related to human activity in the catchment (e.g., agriculture, soil erosion) to some extent.

\subsection{Algae}

Majority of the algae results have been previously published (Tab. 1). The present study briefly describes the significant changes (Tab. 2) that can be seen in Figure 3.

\subsection{Loss-on-ignition}

Mineral matter content varies from site to site, but at least three sites (Kikuru, Āraišu, Trikātas) reflect the anthropogenic signal, most likely agricultural activities around the lakes (Fig. 4). In Lake K,ikuru more mineral matter derived from AD 600-800 and continuously since AD 1000 onwards, and the maximum values reaching AD 1200-1600. In Lake Āraišu pattern is even more evident - 55\% mineral matter content until AD 780 and then abruptly rose up to $70 \%$ and stayed until AD 1980s when it dropped back to 55\%. Lake Lilaste record has only one distinct shift in values at AD 1700-1950 that might be probably due to its size (larger lake blurs the signal unless it is extensive). Lake Trikātas is another site reflecting the clear human impact that begun at AD 1200 with an interesting pattern - two peaks at AD 1400 and AD 1850, and lower values before, in between and after. Lake Lielais Svetinu has relatively low mineral matter content in sediment, but an increasing shift is evident at AD 1750.

\section{Algae beta-diversity (turnover)}

Individual DCCA results of each lake show increasing algae compositional change towards present day (Fig. 4). Lake Kikuru algae turnover rate increases gradually even at an abrupt mineral matter content accumulation at AD 580-700 and since AD 1000 onwards. Soil erosion is pronounced since AD 780 at Lake Āraišu, AD 1200 at Trikātas, AD 1700 at Lilaste and $\mathrm{AD} 1750$ at Lielais Svetinu (Fig. 4). Distinct diatom turnover rates at Lake Āraišu occur at AD 300 and 1950, and turnover of microscopic Chlorophyta and Cyanophyta increases around AD 1200, 1700 and 1950. Two distinct shifts in diatom turnover appear in Trikātas at AD 1200 and AD 1900. Since AD 1300 turnover rate abruptly increases at Lake Lielais Svetinu.

The DCCA results indicate that the highest total turnover (SD 2.66) over the last 2000 years was in Lake Trikātas (Tab. 3, Fig. 5) while the rest of the sites had lower turnover indices. The turnover rates of Lake Āraišu indicated comparable turnover of diatoms (SD 1.21) and microscopic Chlorophyta and Cyanophyta (SD 1.24).

\section{Discussion}

We demonstrated that the algae composition had changed significantly over the last 2000 years with an average algae turnover as high as SD 1.50-2.00 (Fig. 5, Tab. 3). Smaller and larger turnover indices were noted within a relatively small region in northern Latvia, which suggests that the algae had different sensitivities to local environmental changes in the catchment. These differences can be most likely attributed to 
(A) Ķikuru - Chlorophyta \& Cyanophyta

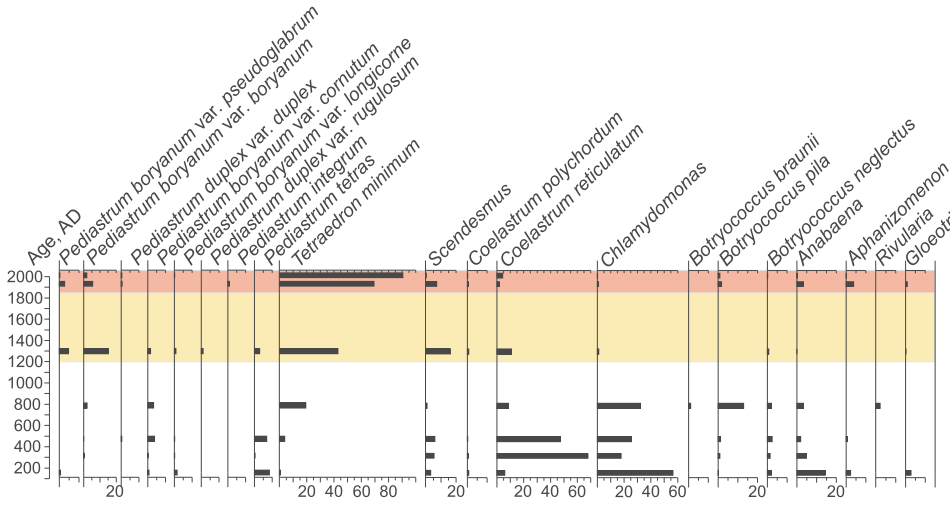

(B) Lilaste - diatoms

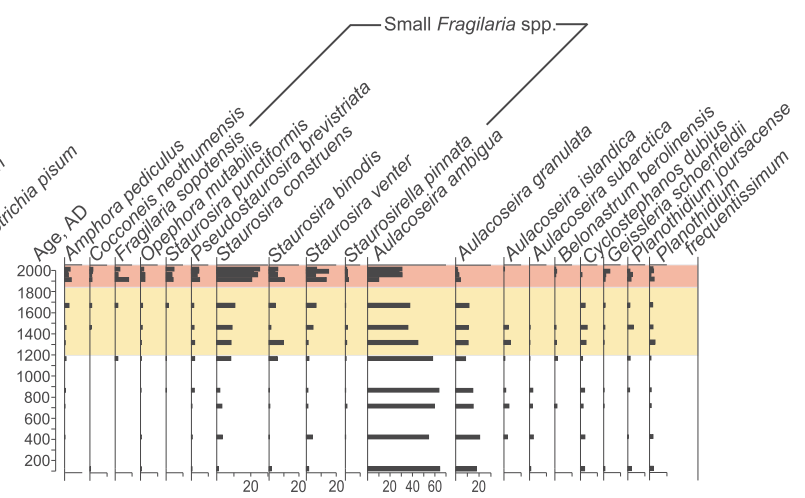

(C) Āraišu - diatoms

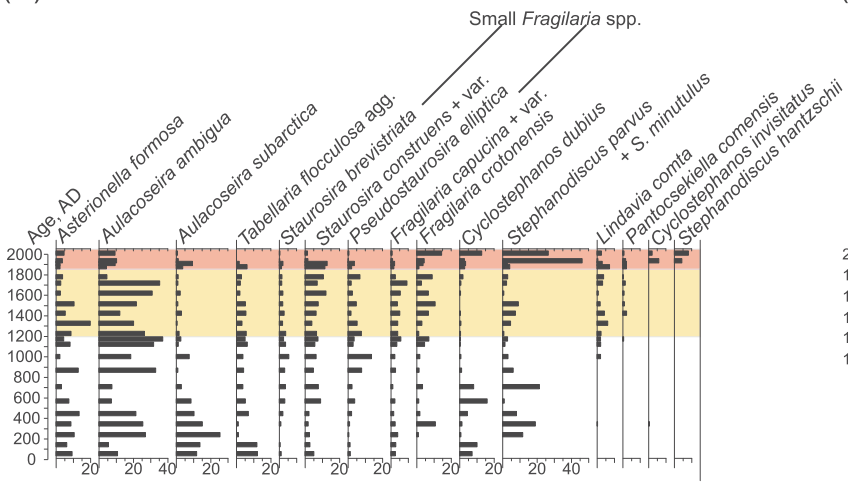

(D) Āraišu - Chlorophyta \& Cyanophyta

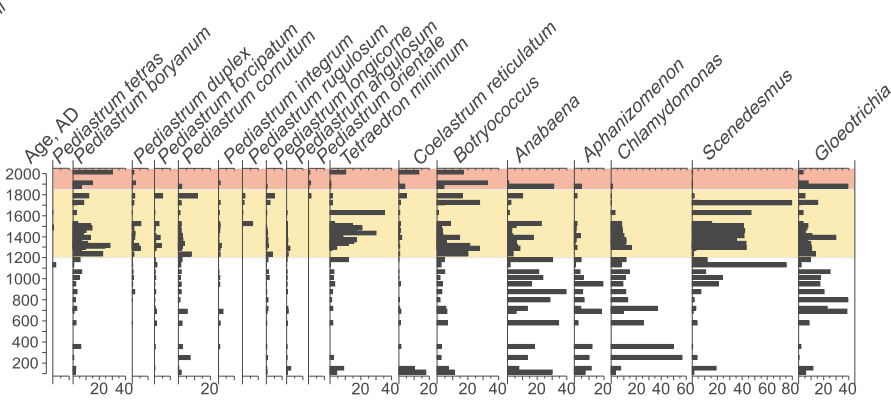

(E) Trikātas - diatoms

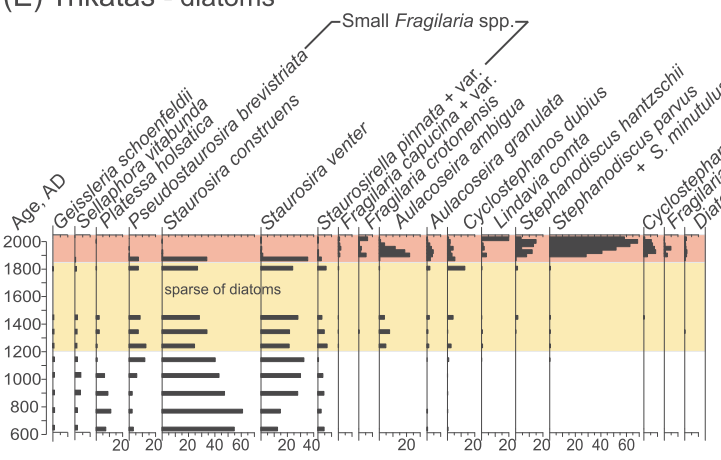

(F) Lielais Svētiṇu - Chlorophyta \& Cyanophyta

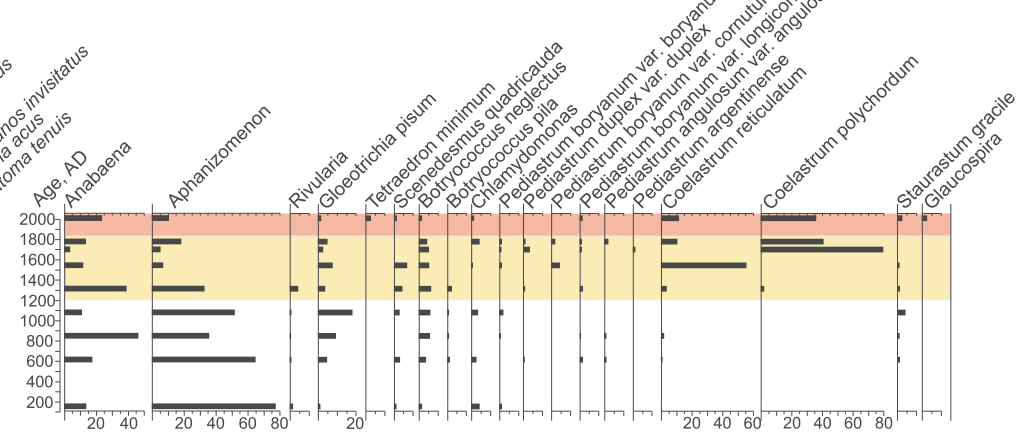

Fig. 3. Diatom and Chlorophyta and Cyanophyta (algae other than diatoms) diagrams of the most common taxa for: (A) Lake Kikuru (Chlorophyta and Cyanophyta; current study); (B) Lake Lilaste (diatom; Grudzinska et al., 2017); (C) Lake Āraišu (diatom; Stivrins et al., 2015a); (D) Lake Āraišu (Chlorophyta and Cyanophyta; Stivrins et al., 2015a); (E) Lake Trikātas (diatom; current study); Lake Lielais Svetiņu (Chlorophyta and Cyanophyta; Stivrins et al., 2015b).

species competition and different tolerances. General patterns in algae composition as seen individually can be discussed within three time frames which are characterised by a general similarity of the algal composition and cultural aspects. To our knowledge, this is the first time when such an analysis has been carried out for diatoms and microscopic Chlorophyta and Cyanophyta (i.e., recovered during a pollen analysis) at the same time. Our results indicate almost same indices of the total turnover rate meaning they both reflect changes similarly. Increasing microscopic Chlorophyta and Cyanophyta data availability from Europe and elsewhere over the last decade allow more intensive comparison studies of diatoms and microscopic Chlorophyta and Cyanophyta now.

\subsection{The Early, Middle and Late Iron Age (AD 1-1200)}

The algal composition was relatively stable during the Early, Middle and Late Iron Age (AD 1-1200) in Lake Trikătas, Lilaste and Lake Lielais Svetinu suggesting minor environmental stress on the lake ecosystems. Landscape 
Table 2. Algae characteristics of study lakes.

\begin{tabular}{|c|c|c|c|c|c|}
\hline Time, AD & Ķikuru & Lilaste & Āraišu & Trikātas & Lielais Svetiṇu \\
\hline $1200-1850$ & $\begin{array}{l}\text { Change in algae } \\
\text { composition that is } \\
\text { evident by increased } \\
\text { Tetraëdron minimum } \\
\text { and Pediastrum } \\
\text { boryanum var. } \\
\text { boryanum suppressing } \\
\text { previously dominating } \\
\text { species. }\end{array}$ & $\begin{array}{l}\text { Gradual increase in } \\
\text { small Fragilaria spp. } \\
\text { suggests higher } \\
\text { turbidity level in the } \\
\text { water column. }\end{array}$ & $\begin{array}{l}\text { Significant variations } \\
\text { in diatom, green algae } \\
\text { and cyanobacteria } \\
\text { composition. } \\
\text { Aulacoseira ambigua } \\
\text { suggests higher } \\
\text { turbulence and mixing } \\
\text { of the water column. }\end{array}$ & $\begin{array}{l}\text { More abundant } \\
\text { planktonic diatom } \\
\text { community that } \\
\text { switched to more } \\
\text { eutrophic conditions. } \\
\text { Aulacoseira ambigua, } \\
\text { Cyclostephanos dubius } \\
\text { and Platessa holsatica } \\
\text { were found this period. }\end{array}$ & $\begin{array}{l}\text { Cyanophyta decrease } \\
\text { and composition switch } \\
\text { in algae by dominance } \\
\text { of Coelastrum reticulatum } \\
\text { and } C \text {. polychordum } \\
\text { suggesting additional } \\
\text { nutrient loading to the lake. }\end{array}$ \\
\hline $1-1200$ & $\begin{array}{l}\text { Algae composition } \\
\text { suggests eutrophic } \\
\text { conditions as } \\
\text { Coelastrum and } \\
\text { Chlamydomonas } \\
\text { overwhelmingly } \\
\text { dominate. }\end{array}$ & $\begin{array}{l}\text { Aulacoseira ambigua } \\
\text { and } A \text {. granulata form } \\
\text { the most common } \\
\text { algae. }\end{array}$ & $\begin{array}{l}\text { Rather stable } \\
\text { assemblage of } \\
\text { phytoplankton } \\
\text { indicating } \\
\text { mesoeutrophic } \\
\text { conditions until AD } \\
\text { 700. Increased amount } \\
\text { of Cyanophyta and } \\
\text { Stephanodiscus parvus } \\
\text { and increase of small } \\
\text { Fragilaria spp. } \\
\text { indicate in-lake } \\
\text { nutrient enrichment } \\
\text { since AD } 800 \text {. }\end{array}$ & $\begin{array}{l}\text { Periphytic diatoms, } \\
\text { e.g., Sellaphora } \\
\text { vitabunda, Platessa } \\
\text { holsatica, suggest a } \\
\text { shallow hard-water } \\
\text { lake with oligo-/ } \\
\text { mesotrophic conditions. } \\
\text { Although dominance of } \\
\text { Staurosira construens } \\
\text { and } S . \text { venter might } \\
\text { show unstable } \\
\text { conditions and higher } \\
\text { turbidity level. }\end{array}$ & $\begin{array}{l}\text { Aphanizomenon and } \\
\text { Anabaena dominates with } \\
\text { increased prevalence of } \\
\text { Gloeotrichia pisum } \\
\text { suggesting Cyanophyta } \\
\text { dominance within the lake. } \\
\text { f }\end{array}$ \\
\hline
\end{tabular}

characteristics such as topography and soil type determined by differences in land access for farming and a low human population density certainly could have limited a pronounced impact on the selected lakes. For instance, although eastern Latvia, particularly the vicinity of Lake Lubāns, has been inhabited since the Palaeolithic (Loze, 1972), the continuous presence of natural forests throughout the Iron Age has been suggested around Lake Lielais Svetinu, which is located only $13 \mathrm{~km}$ to the east (Stivrins et al., 2014). This forest-boggy lowland area was not a suitable or first-choice location for extensive agricultural activity, at least not until AD 1300, so no apparent change in algae composition occurred. The anthropogenic impact on the lakes was comparably low for almost the entire Iron Age even for Lake Kikuru, in which the eutrophic Coelastrum reticulatum and Anabaena, and the hypereutrophic species Chlamydomonas are the most abundant algae (Fig. 4). These species can occur naturally without any effects from human activity (Makohonienko, 2000; Wacnik, 2009; Stivrins et al., 2015b). Indeed, the first pollen results, such as findings of cereal grains of rye and barley, from Lake Kikuru show a distinct increase in human activity around the lake since 11th/12th century (unpublished results).
Although there is an abrupt increase in mineral matter from ca. AD 580 to AD 700 indicating enlarged soil erosion (Fig. 4), there is no direct evidence for the human activities in the vicinity. Spatially synchronised cooling in some parts of Europe was recorded at AD 536-660 (Büntgen et al., 2016) and it is not excluded that the climate cooling with increased precipitation could drive a soil erosion at Lake Kikuru, in western Latvia. Lake Āraišu (Fig. 4) was the only lake that experienced a distinct human-induced environmental change already in Late Iron Age, which was associated with the establishment and inhabitation of a lake-dwelling from AD 780 to 1050 (Stivrins et al., 2015a). This was further evidenced by changes in the proportion of the diatom species. A gradual decrease of Aulacoseira subarctica and a higher abundance of the planktonic diatom Aulacoseira ambigua indicate an increase in nutrient concentrations. In addition, the presence of Cyanophyta and the eutrophic planktonic diatom Stephanodiscus parvus indicates in-lake nutrient enrichment from AD 780 to 1100 , which suggests eutrophication of the lake ecosystem. An increase of small Fragilaria spp. points to unstable conditions caused by increased soil erosion and winddriven mixing of the water column, which might have been 


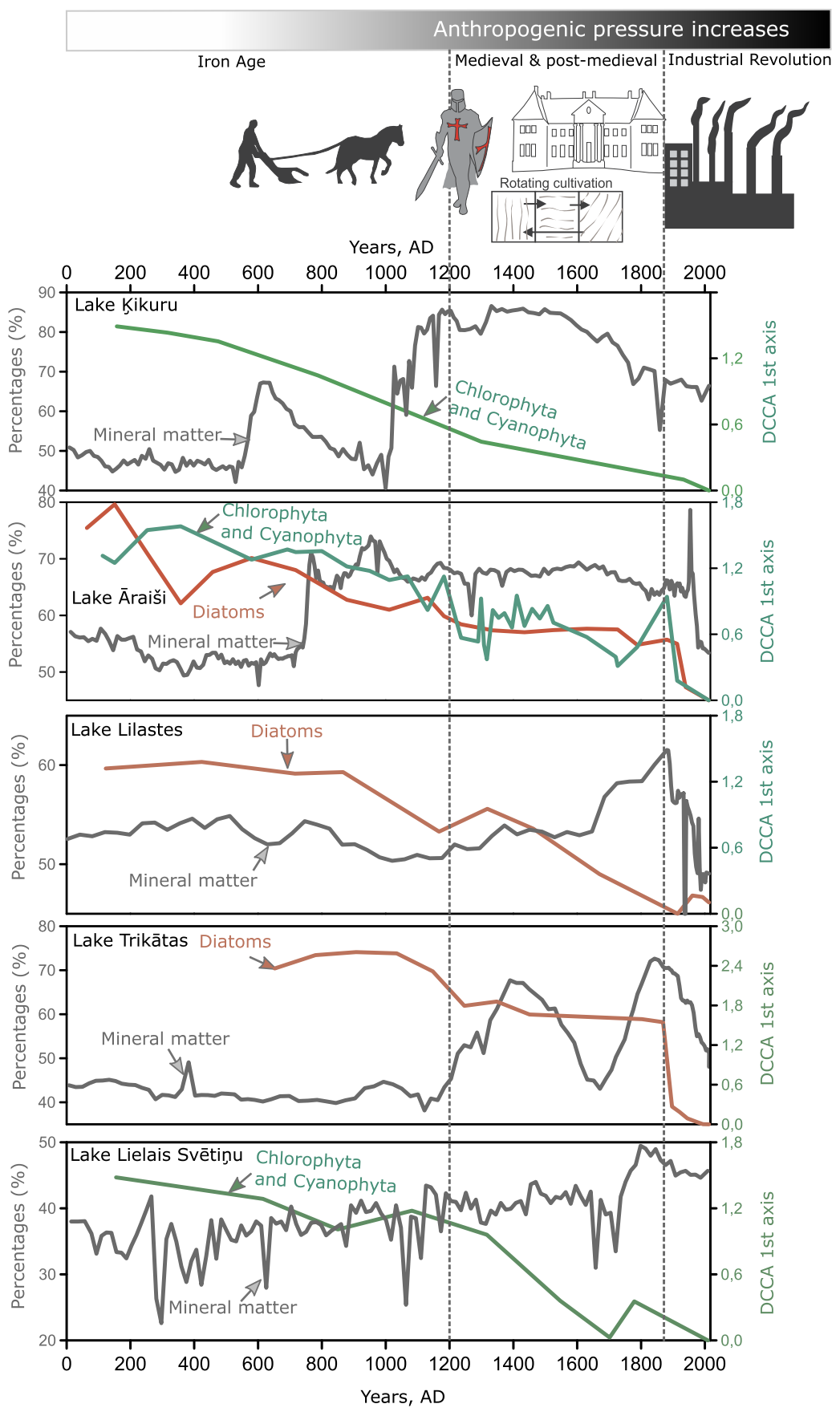

Fig. 4. Compositional algae beta-diversity (1st axis of DCCA) and changes of mineral matter content during the last 2000 years individually for each studied site: (from top) Lake Ķikuru, Lake Āraišu, Lake Lilastes, Lake Trikātas, Lake Lielais Svetinuu. The period division follows the Latvian historical periodisation according to Graudonis (2001) and Vasks et al., (1999).

promoted by clearance of the forest around the lake. Lake eutrophication was most likely a result of intensive arable and pastoral activity, including the rearing of animals within the lake-dwelling (Stivrins et al., 2015a).

\subsection{The Medieval and post-medieval time (AD 1200- 1850)}

The significant shift in the trophic state of the water is associated with the algal compositional turnover occurring during the Medieval and post-medieval period of AD 1200 1850. Significant social, political and economic changes occurred during this period that came along with the Christianization and conquest of present-day Latvia in the Crusades and the subsequent Polish-Lithuanian, Russian and Swedish wars and rule, culminating in the economic growth of the Manor time (Caune and Ose, 2004; Sillasoo and Hiie, 2007; Brown and Pluskowski, 2014; Stivrins et al., 2016a, b). Moreover, technological development such as the rotational crop system increased soil productivity during medieval times; 
Table 3. Summary of the detrended canonical correspondence analyses for the five Latvian study sites; algae used in estimation: diatoms and Chlorophyta and Cyanophyta (i.e., algae other than diatoms); the estimated turnover (beta-diversity) was expressed as the standard deviation (SD); number of samples; number of species.

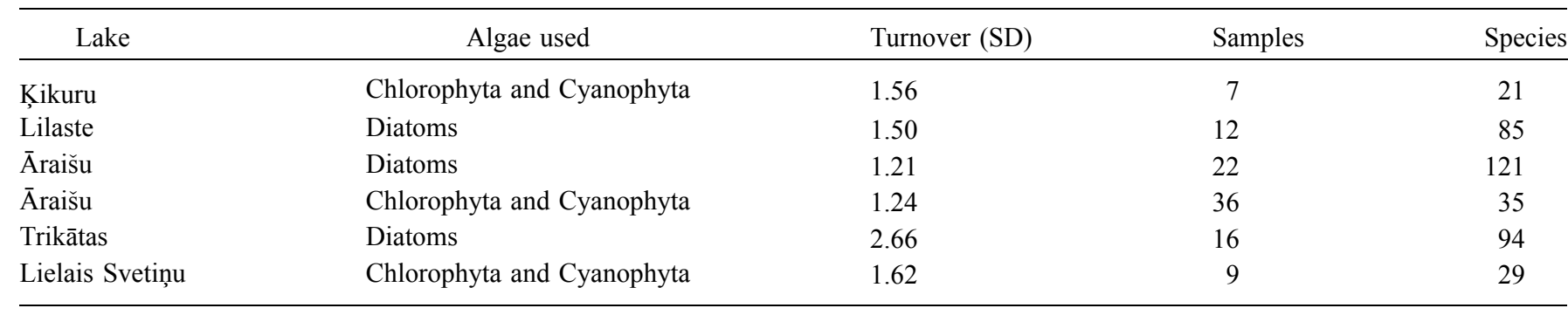

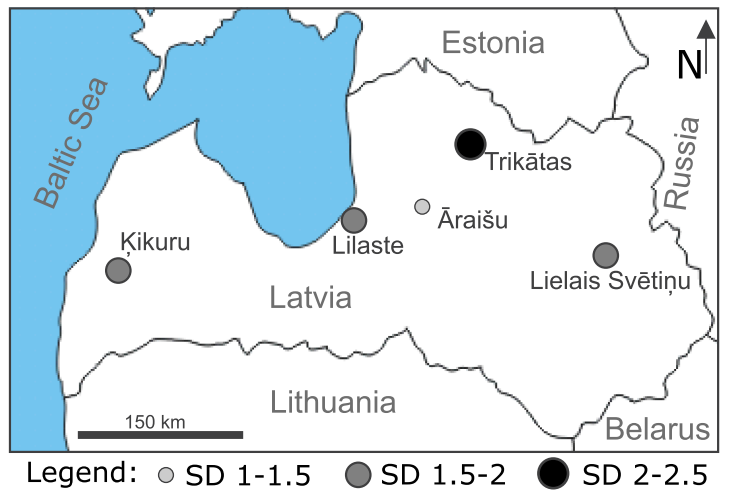

Fig. 5. Total compositional algae beta-diversity during the last 2000 years, expressed in standard deviation (SD) units as estimated by a Detrended Canonical Correspondence Analysis for the five lakes: Ķikuru, Lilaste, Āraišu, Trikātas, and Lielais Svetiņu.

hence, increased food availability allowed the human population and density to grow - increased pressure on the environment. The rotational crop regime became widely accepted and started to replace the previously common slashand-burn technique due to the disadvantages of the latter. The three-field rotational crop system meant cultivation of winter crops in the first field, summer crops in the second and the third was left fallow and cycled back into a crop field in the next year (Enters et al., 2008). The fallow land was most likely used for grazing, so the soil was enriched by herbivore manure that could readily leach and enter a lake. Manure-enriched water leads to lake eutrophication and is characterised by a prevalence of eutrophic algae, for example, Coelastrum reticulatum, Coelastrum polychordum, Gloeotrichia pisum, Anabaena and Aphanizomenon (Fig. 4) (van Geel et al., 1994; Jankovská and Komárek, 2000). Evidence of such processes can be indirectly assessed by finding fossil coprophilous fungal spores in the lake sediment. These spores are known to indicate the presence of herbivores in the vicinity of the lake (van Geel and Aptroot, 2006). By nature, coprophilous fungi spores do not disperse far from their growth substrate, only $20-100 \mathrm{~m}$ on average (Gill et al., 2013). Based on the presence of coprophilous fungi spores the presence of herbivores around the lake during this period has been identified at Lake Āraišu (Stivrins et al., 2015a), Lake Trikātas (unpublished), Lake Lielais Svetinuu (Stivrins et al., 2015b) and Lake Ķikuru (unpublished).
Although the Crusades resulted in significant changes in the organization, ownership and administration of the land, and a shift in the land use patterns, the form and type of agriculture was at first much as it had been during the Late Iron Age (Brown and Pluskowski, 2014; Stivrins et al., 2015a, 2016a). Palaeoecological studies indicate an increase in extensive agricultural land-use a century after the Crusades, i.e., since the 14th century and later (Stivrins et al., 2015a). A rapid increase in the eutrophic algae species, namely, $C$. reticulatum and $C$. polychordum, support an immediate human-induced impact on Lake Lielais Svetinu during the 16 th -17 th century (Fig. 4). Similar compositional changes in other lakes support ongoing algae turnover during the time of the Crusades. The abundance of Staurosira construens and other small Fragilaria spp. since AD 1200 in Lake Lilaste (Figs. 1 and 3) compliment colonisation impact of the Crusades on the environmental conditions and coincide with the foundation of Riga city in AD 1201 (Asaris, 2012). These diatom species suggest a gradual transition to a more dynamic environment (Grudzinska et al., 2017) and might indicate an increased nutrient load from erosive runoff. Similar human-induced activity at all sites appears to fill economic needs, and the development of the Hanseatic League and the manorial system created an increased demand for Baltic timber and agricultural produce (Strods and Zunde, 1999; Stivrins et al., 2016a).

\subsection{The industrial revolution (AD 1850 - present)}

A distinct shift in algae turnover occurred during the last 150 years since the industrial revolution in approximately AD 1850 (Fig. 3), the time when the use of natural resources multiplied to satisfy the growing demand for the production of goods. Several factors affected the algae composition in the lakes, and all are of anthropogenic origin. First, although this time witnessed the peak of extensive agricultural farming, the subsistence extensive farming system was replaced by a more intensive farming economy that resulted in a reduction of land in use (Petit and Lambin, 2002; Veski et al., 2005; Stivrins et al., 2016b). Second, the development of considerable livestock farming along with agricultural farming (Stivrins et al., 2016a) possibly increased the manure input into the lakes. Third, the establishment of distilleries, brick kilns, dairies and other manufacturers, which might have lacked decent sewage cleaning systems, next to a lake or within the lake 
catchment. Notably, during the first years of the manufacture establishment and the Soviet Union occupation period, allowed sewage of different origins directly pass into the lake. High total algae turnover (SD 2.66) has been recorded in Lake Trikătas (Fig. 5) compared with its reference conditions before the intensive human impact indicating a change of more than a half diatom community due to human impact. Thus it could be challenging to restore the water quality to its former status. In Lake Âraišu the first turnover of diatoms occurred around AD 300-400 at the time when the first cereal pollen was detected. Although the human activities were probably of the minor scale, they, however, seem to have influenced aquatic ecosystem. Even though the long-term changes were not as impactful as in Lake Trikātas, a distinct difference from the natural reference conditions is still apparent (SD 1.21-1.24). The status of Lake Āraišu has deteriorated since the 1950s (Fig. 5), as confirmed by the high abundance of eutrophication indicator species such as $S$. parvus, and the appearance of the hypereutrophic diatoms Stephanodiscus hantzschii and Cyclostephanos invisitatus, which indicate in-lake nutrient enrichment and a distinct deterioration of the water quality (Fig. 4).

\section{Conclusions}

In this study, we identified algae from five Latvian lake sediment cores and applied a DCCA to estimate the algae turnover rate for the last 2000 years. Our rationale was to determine the lake reference conditions via a palaeolimnological approach from Latvian lake sediments, for which such work had not been done. Our results revealed that algae composition has significantly changed over the last 2000 years. The average algae turnover was as high as SD 1.50-2.00, which can be directly linked to the growing anthropogenic pressure towards the present day. Human impact has led to great water deterioration in Lake Trikātas, in which the estimated algae turnover reached SD 2.66, indicating a change of more than a half of diatoms composition, so it would be challenging to restore the water quality to its former status. Our results show that the overall algae turnover increased towards the present day with distinct shifts occurring from AD 1200 to 1850 and AD 1850-onwards - a time of extensive and intensive agriculture establishment and political and economic change. Because of the minor anthropogenic impact on the landscape and lakes before AD 1200, we propose that the algae composition at that time can be assumed to represent the natural reference conditions for most Latvian lakes. The results of this study can be further used in restoration activity and environmental management.

Acknowledgements. The study was supported by the Estonian Science Foundation Grant 9031, IUT 1-8, and Doctoral Studies and Internationalisation Programme DoRa. Special gratitude goes to project EBOR (Finland) and the National basic funding for science project Y5-AZ03-ZF-N-110 "Dabas resursu ilgtspejīga izmantošana klimata pārmaiņu kontekstā" Nr. ZD2010/AZ03 (Latvia). Likewise, we wish to thank Vita Ratniece for providing with additional data for this study.

\section{References}

Alliksaar T. 2000. Spatial and temporal variability of the distribution of spherical fly-ash particles in sediments in Estonia. Tallinn Pedagogical University, Dissertations on Natural Sciences, 4: 1-44.

Alliksaar T, Heinsalu A. 2012. A radical shift from soft-water to hardwater lake: palaeolimnological evidence from Lake Kooraste Kõverjärv, southern Estonia. Est J Earth Sci 61: 317-327.

Asaris G. 2012. Riga: Entering the 21st Century. In: Ziemelniece A, ed. Proceedings of the Latvian University of Agriculture. Landscape Architecture and Art, Vol. 1, pp. 5-9.

Battarbee RW, Bennion H. 2011. Palaeolimnology and its developing role in assessing the history and extent of human impact on lake ecosystems. J Paleolimnol 45: 399-404.

Battarbee R, Jones VJ, Flower RJ, et al. 2001. Diatoms. In: Smol JP, Birks HJB, Last W, eds. Tracking environmental change using lake sediments, vol. 3., Terrestrial, algal, and siliceous indicators. Dordrecht: Kluwer Academic Publishers, pp. 155-202.

Bellinger EG, Sigee DC. 2010. Freshwater algae. Identification and use as bioindicators. Chichester: John Wiley and Sons, 285 p, ISBN 978-0-470-05814-5.

Berglund BE, Ralska-Jasiewiczowa M. 1986. Pollen analysis and pollen diagrams. In: Berglund B, ed. Handbook of holocene palaeoecology and palaeohydrology. New York: Wiley, pp. 455-484.

Birks HJB. 2007. Estimating the amount of compositional change in late-Quaternary pollen-stratigraphical data. Veg Hist Archaeobot 16: 197-202.

Birks HJB, Birks HH. 2008. Biological responses to rapid climate change at the Younger Dryas-Holocene transition at Kråkenes, western Norway. Holocene 18: 19-30.

Blaauw M, Christen JA. 2011. Flexible paleoclimate age-depth models using an auto-regressive gamma process. Bayesian Anal 6: 457-474.

Bradshaw EG, Rasmussen P, Vad Odgaard B. 2005. Mid- to lateHolocene land-use change and lake development at Dallund Sø, Denmark: synthesis of multiproxy data, linking land and lake. Holocene 8: 1152-1162.

Brown A, Pluskowski A. 2014. Medieval landscape transformation in the southeast and eastern Baltic: palaeoenvironmental perspectives on the colonisation of frontier landscapes. Archaeol Balt 20: 24-46.

Büntgen U, Myglan VS, Ljungqvist FC, et al. 2016. Cooling and societal change during the Late Antique Little Ice Age from 536 to around 660 AD. Nat Geosci 9: 231-236.

Caune A, Ose I. 2004. Latvijas 12. gadsimta beigu- -17 gadsimat vācu pilu leksikons. Rīga: Latvijas Vestures Instituts. (in Latvian)

De Senerpont Domis LN, Elser JJ, Gsell AS, et al. 2013. Plankton dynamics under different climatic conditions in space and time. Freshw Biol 58: 463-482.

Douglas I, James P. 2015. Urban ecology, an introduction. New York: Routledge, $472 \mathrm{p}$.

Douglas MSV, Smol JP. 1999. Freshwater diatoms as indicators of environmental change in the High Arctic. In: Stoermer EF, Smol JP, eds. The diatoms: applications for the environmental and Earth sciences. Cambridge: Cambridge University Press, pp. 227-244.

EC [European Community]. 2000. Directive 2000/60/EC of the European Parliament and of the Council of 23 October 2000 establishing a framework for Community action in the field of water policy. Off J Eur Commun 327: 1-71.

Enters D, Dörfler W, Zolitschka B. 2008. Historical soil erosion and land-use change during the last two millennia recorded in lake sediments of Frickenhauser See, northern Bavaria, central Germany. Holocene 18: 243-254. 
Gill JL, McLauchlan KK, Skibbe AM, Goring S, Zirbel CR, Williams JW. 2013. Linking abundance of the dung fungus Sporormiella to the density of bison: implications for assessing grazing by megaherbivores in palaeorecords. J Ecol 101: 1125-1136.

Graudonis J. 2001. Early Metal Period. In: Graudonis J, ed. The prehistory of Latvia. Riga: Institute of the history of Latvia. pp. 40.

Grudzinska I, Vassiljev J, Saarse L, Reitalu T, Veski S. 2017. Past environmental change and seawater intrusion into coastal Lake Lilaste, Latvia. J Paleolimnol 57: 257-271.

Heinsalu A, Alliksaar T. 2009a. Palaeolimnological assessment of environmental change over the last two centuries in oligotrophic Lake Nohipalu Valgjärv, southern Estonia. Est J Earth Sci 58: 124132.

Heinsalu A, Alliksaar T. 2009b. Palaeolimnological assessment of the reference conditions and ecological status of lakes in Estonia implications for the European Union Water Framework Directive. Est J Earth Sci 58: 334-341.

Heiri O, Lotter AF, Lemcke G. 2001. Loss on ignition as a method for estimating organic and carbonate content in sediments: reproducibility and comparability of results. J Paleolimnol 25: 101-110.

Hering D, Borja A, Carstensen J, et al. 2010. The European Water Framework Directive at the age of 10: a critical review of the achievements with recommendations for the future. Sci Total Environ 408: 4007-4019.

Hill MO, Gauch HG. 1980. Detrended correspondence analysis, an improved ordination technique. Vegetatio 41: 47-58.

IPCC. 2014. Climate Change 2014: Synthesis Report. In: Core Writing Team, Pachauri RK, Meyer LA, eds. Contribution of Working Groups I, II and III to the Fifth Assessment Report of the Intergovernmental Panel on Climate Change. Geneva (Switzerland): IPCC, pp.151.

Jankovská V, Komárek J. 2000. Indicative value of Pediastrum and other coccal green algae in palaeoecology. Folia Geobot 35: 59-82.

Krammer K, Lange-Bertalot H. 1986. Bacillariophyaceae 1.Teil Naviculaceae. In: Ettl H, Gerloff J, Heying H, Mollenhauser D, eds. Süsswasserflora von Mitteleuropa 2/1. Stuttgart: Gustav Fisher Verlag.

Krammer K, Lange-Bertalot H. 1988. Bacillariophyaceae 2.Teil Bacillariaceae, Epithemiaceae, Surirellaceae. In: Ettl H, Gerloff J, Heying H, Mollenhauser D, eds. Süsswasserflora von Mitteleuropa 2/2. Stuttgart: Gustav Fisher Verlag.

Krammer K, Lange-Bertalot H. 1991a. Bacillariophyaceae 3.Teil Centrales, Fragilariceae, Eunotiaceae. In: Ettl H, Gerloff J, Heying H, Mollenhauser D, eds. Süsswasserflora von Mitteleuropa 2/3. Stuttgart: Gustav Fisher Verlag.

Krammer K, Lange-Bertalot H. 1991b. Bacillariophyaceae 4.Teil Achnanthaceae. In: Ettl H, Gerloff J, Heying H, Mollenhauser D, eds. Süsswasserflora von Mitteleuropa 2/4. Stuttgart: Gustav Fisher Verlag.

Liu X, Sheng H, Jiang S, Yuan Z, Zhang C, Elser JJ. 2016. Intensification of phosphorus cycling in China since the 1600 s. PNAS 113: 2609-2614.

Loze I. 1972. Stoianka Lagazha (Lubaskaia nizmennostj). Latvijas PSR Zintātñu Akademijas Vestis 6, 57-73. (in Russian)

Makohonienko M. 2000. Przyrodnicza historia Gniezna. Prace zakładu biogeografii i paleoekologii UAM. Homini, BydgoszczPoznań. (in Polish)

Marzecová A, Avi E, Mikomägi A, Koff T. 2017. Ecological response of a shallow boreal lake to biomanipulation and catchment landuse: integrating paleolimnological evidence with information from limnological surveys and maps. J Paleolimnol 57: 1-18.
Mikomägi A, Koff T, Martma T, Marzecová A. 2016. Biological and geochemical records of human-induced eutrophication in a small hard-water lake. Boreal Environ Res 21: 513-527.

O'Reilly CM, Sharma S, Gray DK, et al. 2015. Rapid and highly variable warming of lake surface water around the globe. Geophys Res Lett 42: 1-9.

Paerl HW, Huisman J. 2008. Blooms like it hot. Science 320: 57-58.

Park Y-S. 2016. Aquatic ecosystem assessment and management. Ann Limnol - Int J Limnol 52: 61-63.

Petit CC, Lambin EF. 2002. Long-term land-cover changes in the Belgian Ardennes (1775-1929): model-based reconstruction vs. historical maps. Glob Chang Biol 8: 616-630.

R Core Team. 2014. R: A language and environment for statistical computing. Vienna: R Foundation for Statistical Computing, http:// www.R-project.org/

Reimer PJ, Bard E, Bayliss A, et al. 2013. IntCal13 and Marine13 radiocarbon age calibration curves, 0-50 000 years cal BP. Radiocarbon 55: 1869-1887.

Rose N. 1990. A method for the selective removal of inorganic ash particles from lake sediments. J Paleolimnol 4: 61-68.

Schiefer E, Petticrew EL, Immell R, Hassan MA, Sonderegger DL. 2013. Land use and climate change impacts on lake sedimentation rates in western Canada. Anthropocene 3: 61-71.

Sillasoo Ü, Hiie S. 2007. An archaeobotanical approach to investigating food of the Hanseatic period in Estonia. In: Karg S, ed. Medieval Food Traditions in Northern Europe. Copenhagen, National Museum of Denmark, pp. 73-96.

Smith SJ, Edmonds J, Hartin CA, Mundra A, Calvin K. 2015. Nearterm acceleration in the rate of temperature change. Nat Clim Chang 5: 333-336.

Smol JP. 2008. Pollution of lakes and rivers, a paleoenvironmental perspective, second edition. Blackwell Publishing, $400 \mathrm{p}$.

Smol JP, Wolfe AP, Birks HJB, et al. 2005. Climate-driven regime shifts in the biological communities of arctic lakes. PNAS 102: 4397-4402.

Soininen J, Bartels P, Heino J, Luoto M, Hillebrand H. 2015. Toward more integrated ecosystem research in aquatic and terrestrial environments. Bioscience 65: 174-182.

Steffen W, Broadgate W, Deutsch L, Gaffney O, Ludwig C. 2015. The trajectory of the Anthropocene: the great acceleration. Anthropocene Rev 2: 81-98.

Stivrins N, Kalnina L, Veski S, Zeimule S. 2014. Local and regional Holocene vegetation dynamics at two sites in eastern Latvia. Boreal Environ Res 19: 310-322.

Stivrins N, Brown A, Reitalu T, et al. 2015a. Landscape change in central Latvia since the Iron Age: multi-proxy analysis of the vegetation impact of conflict, colonisation and economic expansion during the last 2000 years. Veg Hist Archaeobot 24: 377-391.

Stivrins N, Kołaczek P, Reitalu T, Seppä H, Veski S. 2015b. Phytoplankton response to the environmental and climatic variability in a temperate lake over the last 14500 years in eastern Latvia. J Paleolimnol 54: 103-119.

Stivrins N, Brown A, Veski S, et al. 2016a. Palaeoenvironmental evidence for the impact of the crusades on the local and regional environment of medieval (13th-16th century) northern Latvia, eastern Baltic. Holocene 26: 61-69.

Stivrins N, Wulf S, Wastegård S, et al. 2016b. Detection of the Askja AD 1875 cryptotephra in Latvia, Eastern Europe. J Quat Sci 31: 437-441.

Stivrins N, Liiv M, Heinsalu A, Gałka M, Veski S. 2017. The final melt-out of dead-ice at Holocene Thermal Maximum (8500-7400 cal yr BP) in western Latvia. Holocene 27: 1146-1157. 
Stivrins N, Soininen J, Tõnno I, Freiberg R, Veski S, Kisand V. 2018. Towards understanding the abundance of non-pollen palynomorphs: a comparison of fossil algae, algal pigments and sedaDNA from temperate lake sediments. Rev Palaeobot Palynol 249: 9-15.

Strods H, Zunde M. 1999. Latvijas meža vesture līdz 1940. gadam. Rīga: Pasaules dabas fonds, 363 p. (in Latvian)

ter Braak CJF, Šmilauer P. 2012. Canoco reference manual and user's guide: software for ordination (version 5.0). New York, Ithaca (USA): Microcomputer Power, 496 p.

van Geel B, Aptroot A. 2006. Fossil ascomycetes in Quaternary deposits. Nova Hedwig 82: 313-329.

van Geel B, Mur LR, Ralska-Jasiewiczowa M, Goslar T. 1994. Fossil akinetes of Aphanizomenon and Anabaena as indicators for medieval phosphate-eutrophication of Lake Gosciaz (Central Poland). Rev Palaeobot Palynol 83: 97-105.

Vasks A, Kalnina L, Ritums R. 1999. The introduction and preChristian history of farming in Latvia. In: Miller U, Hackens T, Lang V, Raukas A, Hicks S, eds. Environmental and Cultural History of the Eastern Baltic Region. PACT, Vol. 57, pp. 291-304.
Veski S, Koppel K, Poska A. 2005. Integrated palaeoecological and historical data in the service of fine-resolution land use and ecological change assessment during the last 1000 years in Rōuge, southern Estonia. J Biogeogr 32: 1473-1488.

Wacnik A. 2009. Vegetation development in the Lake Miłkowskie area, north-eastern Poland, from the Plenivistulian to the late Holocene. Acta Palaeobot 49: 287-335.

Wang C, Liu Y, Li X, Lai Z, Tackx M, Lek S. 2015. A bibliometric analysis of scientific trends in phytoplankton research. Ann Limnol - Int J Limnol 51: 249-259.

Weckström J, Lia M, Yu G, et al. 2015. Responses of aquatic ecosystems to environmental changes in Finland adn China. Front Ecol Evol 3: 1-14.

Witkowski A, Lange-Bertalot H, Metzeltin D. 2000. Diatom Flora of Marine Coasts I. Iconographia Diatomologica 7. A.R.G. Gantner Verlag K.G., Ruggell (Liechtenstein), 925 p.

Zelčs V, Markots A, Nartišs M, Saks T. 2011. Pleistocene glaciations in Latvia. In: Ehlers J, Gibbard PL, Huges PD, eds. Quaternary glaciations-extent and chronology, a closer look. Amsterdam: Elsevier, pp. 221-229.

Cite this article as: Stivrins N, Grudzinska I, Elmi K, Heinsalu A, Veski S. 2018. Determining reference conditions of hemiboreal lakes in Latvia, NE Europe: a palaeolimnological approach. Ann. Limnol. - Int. J. Lim. 54: 22 